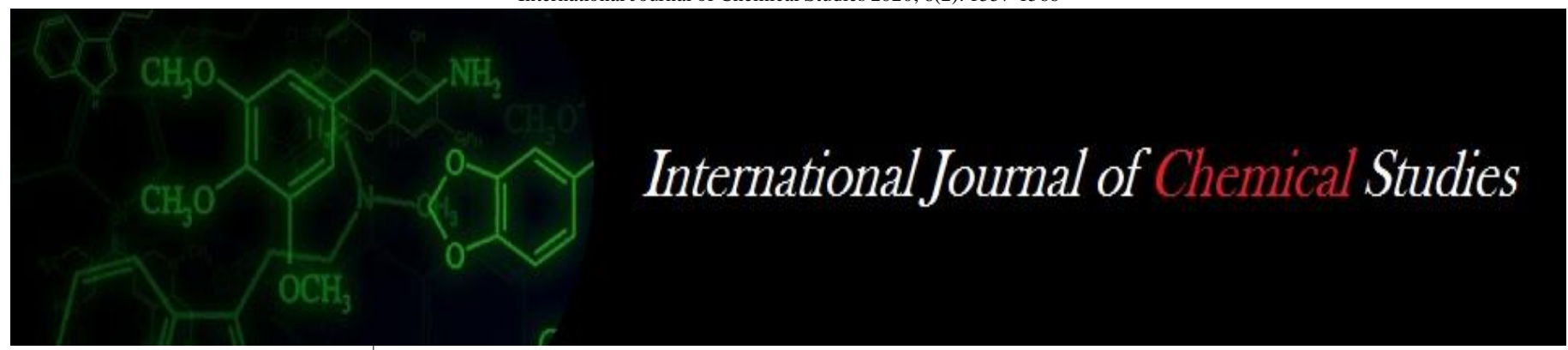

P-ISSN: 2349-8528

E-ISSN: 2321-4902

www.chemijournal.com

IJCS 2020; 8(2): 1557-1566

(C) 2020 IJCS

Received: 16-01-2020

Accepted: 20-02-2020

Ashwani

Department of Soil and Water

Engineering, College of

Agricultural Engineering and

Technology, CCS Haryana

Agricultural University, Hisar,

Haryana, India

\section{Sanjay Kumar}

Department of Soil and Water

Engineering, College of

Agricultural Engineering and

Technology, CCS Haryana

Agricultural University, Hisar,

Haryana, India

\section{RK Jhorar}

Department of Soil and Water

Engineering, College of

Agricultural Engineering and

Technology, CCS Haryana

Agricultural University, Hisar,

Haryana, India

\section{Rahul Makkar}

Department of Soil and Water

Engineering, College of

Agricultural Engineering and

Technology, CCS Haryana

Agricultural University, Hisar,

Haryana, India

\section{Corresponding Author:}

Rahul Makkar

Department of Soil and Water

Engineering, College of

Agricultural Engineering and

Technology, CCS Haryana

Agricultural University, Hisar,

Haryana, India

\section{Response of chilli crop to different nitrogen fertigation and irrigation frequency under drip system using marginally saline water}

\author{
Ashwani, Sanjay Kumar, RK Jhorar and Rahul Makkar
}

DOI: https://doi.org/10.22271/chemi.2020.v8.i2x.8984

\begin{abstract}
In India, sustainable development and efficient management of water is a complex challenge which is going to increase day by day. Some parts of Haryana and Punjab are underlain by brackish to saline groundwater and inadequate canal network. Areas which mainly depend on canal water irrigation which restrict the pumping of saline groundwater and develop waterlogging as well as soil salinization with a rapid rise of the water table. In this situation, its exploitation is necessary to arrest the rise in water table and saline water use for crop production. This study aimed to explore the performance of chilli crop in relation to differential nitrogen and irrigation using marginally saline water under drip system. Irrigation of marginal quality $\left(\mathrm{EC} \sim 2.5 \mathrm{dS} \mathrm{m}{ }^{-1}\right)$ water was scheduled on daily $\left(\mathrm{I}_{1}\right)$ and alternate day $\left(\mathrm{I}_{2}\right)$ bases with combination of three fertigation levels $\left(\mathrm{F}_{1}: 75 \% \mathrm{RDN}, \mathrm{F}_{2}: 100 \% \mathrm{RDN}\right.$ and $\left.\mathrm{F}_{3}: 125 \% \mathrm{RDN}\right)$ and surface irrigation $\left(\mathrm{S}_{\mathrm{i}}\right)$ with $100 \% \mathrm{RDN}$ as control with three replication. The highest yield $\left(10.69 \mathrm{t} \mathrm{ha}^{-1}\right)$ was obtained under daily drip irrigation with $125 \% \mathrm{RDN}\left(\mathrm{I}_{1} \mathrm{~F}_{3}\right)$, followed by $100 \% \mathrm{RDN}\left(\mathrm{I}_{1} \mathrm{~F}_{2}\right)$ having $10.23 \mathrm{t}$ ha $^{-1}$ yield. In daily irrigation, $28.2 \%$ and $34.0 \%$ more yield was obtained in $\mathrm{I}_{1} \mathrm{~F}_{2}$ and $\mathrm{I}_{1} \mathrm{~F}_{3}$ in comparison to $\mathrm{I}_{1} \mathrm{~F}_{1}$. Among the drip irrigation, $\mathrm{I}_{1} \mathrm{~F}_{3}$ treatment has obtained the highest water use efficiency $\left(4.17 \mathrm{~kg} \mathrm{~m}^{-3}\right)$ and its lowest value $3.19 \mathrm{~kg} \mathrm{~m}^{-3}$ was obtained in $\mathrm{I}_{2} \mathrm{~F}_{1}$ treatment. The highest NUE (172.2 $\mathrm{kg}$ of chilli per $\mathrm{kg}$ of Nitrogen) was obtained under daily drip irrigation with $75 \% \mathrm{RDN}\left(\mathrm{I}_{1} \mathrm{~F}_{1}\right)$, followed by $100 \% \mathrm{RDN}$ (165.6 kg of chilli per $\mathrm{kg}$ of Nitrogen). The highest nitrogen uptake $\left(64.99 \mathrm{~kg} \mathrm{ha}^{-1}\right)$ was obtained under daily drip irrigation with $125 \%$ RDN $\left(\mathrm{I}_{1} \mathrm{~F}_{3}\right)$, followed by $100 \% \mathrm{RDN}\left(\mathrm{I}_{1} \mathrm{~F}_{2}\right)$ having $61.68 \mathrm{~kg} \mathrm{ha}^{-1}$. With respect to irrigation frequencies as well as different RDN levels, nitrogen uptake was found significantly different.
\end{abstract}

Keywords: Drip, irrigation frequency, saline water, WUE, chilli

\section{Introduction}

In India, sustainable development and efficient management of water is a complex challenge which is going to increase day by day. Efficient management of water resources is essential to meet the increasing competition for water between agricultural and non-agricultural sectors. Around 50\% increase in demand for water by the year 2025 can be met out by increasing the effectiveness of irrigation (Seckler et al., 1998) ${ }^{[17]}$. Therefore, conservation of water resources, utilization of salt affected land and water resources in a most productive manner and improved irrigation techniques including micro irrigation would play an important role.

Drip irrigation is one of the best techniques for applying water to widely spaced row planted crops, especially in the water scarce areas. It is a technique in which water is applied directly to every individual plant on a steady and incessant basis (Schwab et al., 1993) ${ }^{[16]}$. This technology not only uses each drop of water most efficiently but also results in good crop growth and yield. It maintains stable moisture content in the root zone by applying frequent and regular irrigation at shorter intervals. It has most significant role to achieve not only higher productivity and water use efficiency but also have sustainability with economical use.

It is essential to use marginal quality water for irrigation because of less availability of fresh water. However, it is important to know that development of excess soil salinity in the root zone by the use of saline water may also inhibit normal crop growth and development (Kelley, 1951) ${ }^{[13]}$. The surface irrigation methods including the border strips, check basins and furrows are the oldest and most commonly practiced in most parts of the India. Use of saline water without drip irrigation decreases fruit yield by reducing both fruit weight and number. 
Crops can tolerate saline environment better under drip than any surface irrigation method because of low metric stress near the roots that is a characteristic of the drip irrigation. Drip irrigation gave higher crop yield than any methods of irrigation with different level of saline.

Chilli is an important spice and vegetable crop cultivated extensively in India. India is the largest producer and exporter of chillies and the major chillies producing states are Andhra Pradesh, Karnataka, Maharashtra, Orissa, Tamil Nadu, West Bengal, Madhya Pradesh, Rajasthan, Gujarat, Punjab and Haryana. According to an estimation of 2016-17, in India, chillies (fresh-green fruits) were cultivated on 316,000 ha with a total production of 3.6 million $t$ of fresh fruits and 840,000 ha area with a total production of 2.1 million $t$ of dry fruits as spices. The chilli fruits are available in the market throughout the year as it is grown during all seasons of the year in the country (Dahal et al., 2006) ${ }^{[4]}$. It is used in salads, sauce, pickles and as a main ingredient of Indian diet in each home. It is a rich source of vitamin ' $A$ ' and vitamin ' $C$ ' with plenty of minerals.

In the most productive north-western Indian states i.e. Haryana, Punjab and western Uttar Pradesh due to inadequate canal network, the sustainability of agriculture is getting threatened due to decline of water table Some parts of Haryana and Punjab is underlain by brackish to saline groundwater and mainly depends on canal water irrigation which restrict the pumping of saline groundwater and develop waterlogging as well as soil salinization with a rapid rise of the water table. In this situation, its exploitation is necessary to arrest the rise in water table and saline water use for crop production. In Haryana state 37 percent of groundwater is of good quality, $8 \%$ marginal and $55 \%$ are of poor quality. Among proor quality water $18 \%$ is sodic, $11 \%$ saline and $26 \%$ saline sodic in nature (Manchanda, 1976).

The ability of drip irrigation to apply water as well as fertilizers on demand, offer great scope for efficient resource management as well as challenge to researchers to identify suitable irrigation and fertigation schedules for drip irrigated crops. The present study was undertaken to address keeping some of the above-mentioned points. The present study was undertaken to address keeping some of the above-mentioned points.

\section{Material and methods}

A field experiment was carried out in micro plots (2 m x $2 \mathrm{~m}$ ) constructed in lab area of Department of Soil and Water Engineering, COAE\&T, CCSHAU, Hisar (29009'0.97'N latitude and 75042'20.12'E longitude) during 11 August, 2017 to 10 December, 2017. Irrigation was applied daily and alternate day with marginal quality water $\left(\mathrm{EC} \sim 2.5 \mathrm{dS} \mathrm{m}^{-1}\right)$ under drip along with three nitrogen fertigation levels (i.e. $75 \%, 100 \%$ and $125 \%$ of recommended dose of Nitrogen). For crop establishment good quality water $\left(\mathrm{EC} \sim 0.5 \mathrm{dS} \mathrm{m}^{-1}\right)$ was applied during the initial 15 days of transplanting. To compare the results of drip irrigation, one treatment of control was composed with surface irrigation having $100 \%$ RDN. A summary of different treatments with abbreviation is given in Table 1.

Table 1: Different treatments of nitrogen fertigation

\begin{tabular}{|c|c|c|}
\hline S. No. & Treatments & Abbreviation \\
\hline 1 & Surface irrigation with 100\% RDN & $\mathrm{S}_{\mathrm{i}}$ \\
\hline 2 & Daily Irrigated with $75 \%$ RDN by drip System & $\mathrm{I}_{1} \mathrm{~F}_{1}$ \\
\hline 3 & Daily irrigated with 100\% RDN by drip system & $\mathrm{I}_{1} \mathrm{~F}_{2}$ \\
\hline 4 & Daily irrigated with 125\% RDN by drip system & $\mathrm{I}_{1} \mathrm{~F}_{3}$ \\
\hline 5 & Alternate day irrigated with 75\% RDN by drip system & $\mathrm{I}_{2} \mathrm{~F}_{1}$ \\
\hline 6 & Alternate day irrigated with 100\% RDN by drip system & $\mathrm{I}_{2} \mathrm{~F}_{2}$ \\
\hline 7 & Alternate day irrigated with 125\% RDN by drip system & $\mathrm{I}_{2} \mathrm{~F}_{3}$ \\
\hline
\end{tabular}

RDN - Recommended dose of Nitrogen

FYM @ 8 kg per plot and 100\% of P and K was applied before transplanting the chilli. Recommended dose of nitrogen is $62 \mathrm{~kg} / \mathrm{ha}$ and was equally split in 14 doses and applied weekly from the first week of transplanting. To maintain the uniform distribution of water through drip irrigation, drippers discharge was checked randomly and average drip discharge was estimated as $1.8 \mathrm{l} / \mathrm{h}$ with 92 percent uniformity coefficient. The amount of irrigation water required to apply was estimated by using the following formula (Schwab et al., 1993) ${ }^{[16]}$ was used.

$$
V=\frac{E_{p} \times K_{c} \times K_{p} \times P P \times R R \times P}{10 \times E_{a} \times 85}
$$

Where $\mathrm{V}=$ Volume of water to be applied (ml/plant); $\mathrm{E}_{\mathrm{p}}=$ Evaporation of the day $(\mathrm{mm}) ; \mathrm{K}_{\mathrm{c}}=$ Crop coefficient (given in Table 2); $\mathrm{K}_{\mathrm{p}}=$ pan coefficient as 0.85 ; $\mathrm{PP}=$ plant to plant spacing $(50 \mathrm{~cm}) ; \mathrm{RR}=$ row to row spacing $(50 \mathrm{~cm}) ; \mathrm{E}_{\mathrm{a}}=$ irrigation efficiency (assumed as $90 \%$ ); $\mathrm{P}=\%$ of area shaded by crop (minimum value was taken as $15 \%$ ).

Under daily drip irrigation, the amount of water calculated from the above formula was applied, whereas, under alternate day drip irrigation the amount of water was calculated by adding previous two days pan-evaporation. For surface irrigation, water was applied at four to five days interval and amount of water was estimated by adding previous four to five days pan-evaporation. Table 2 shows the physical and chemical properties of experimental site.

Table 2: Physical and chemical properties of experimental site

\begin{tabular}{|c|c|c|c|c|}
\hline \multirow{2}{*}{ Parameters/Properties } & \multicolumn{4}{|c|}{ Soil depth (cm) } \\
\cline { 2 - 5 } & $\mathbf{0 - 1 5}$ & $\mathbf{1 5 - 3 0}$ & $\mathbf{3 0 - 4 5}$ & $\mathbf{4 5 - 6 0}$ \\
\hline Sand (\%) & 88 & 88 & 88 & 88 \\
\hline Silt (\%) & 4 & 4 & 4 & 4 \\
\hline Clay (\%) & 8 & 8 & 8 & 8 \\
\hline Texture & Loamy Sand & Loamy Sand & Loamy Sand & Loamy Sand \\
\hline Bulk density & 1.54 & 1.55 & 1.55 & 1.52 \\
\hline $\mathrm{pH}$ & 8.01 & 8.04 & 8.17 & 8.12 \\
\hline
\end{tabular}




\begin{tabular}{|c|c|c|c|c|}
\hline $\mathrm{EC}_{1: 2}$ & 0.24 & 0.18 & 0.18 & 0.22 \\
\hline $\mathrm{N}\left(\mathrm{kg} \mathrm{ha}^{-1}\right)$ & 104.12 & 108.73 & 104.20 & 106.53 \\
\hline $\mathrm{P}\left(\mathrm{kg} \mathrm{ha}^{-1}\right)$ & 0.22 & 0.26 & 0.20 & 0.23 \\
\hline $\mathrm{K}\left(\mathrm{kg} \mathrm{ha}^{-1}\right)$ & 19.90 & 22.52 & 21.54 & 23.67 \\
\hline Organic carbon $(\%)$ & 0.25 & 0.23 & 0.25 & 0.24 \\
\hline Basic infiltration rate & \multicolumn{2}{|c|}{$2.96 \mathrm{~cm} \mathrm{~h}^{-1}$} \\
\hline
\end{tabular}

\subsection{Moisture and salt distribution measurement}

Soil samples were collected randomly from the field at $0-15$, $15-30,30-45$ and $45-60 \mathrm{~cm}$ depth from the surface of the soil in vertical direction and at $0,12.5$ and $25 \mathrm{~cm}$ distance in horizontal direction from the dripper. Soil moisture was determined by gravimetric method in which samples were dried in oven for 24 hour at $105^{\circ} \mathrm{C}$. EC of the soil sample was measured in the form of $\mathrm{EC}_{1: 2}$ in which one part of soil and 2 part of water was taken. For measurement of $\mathrm{EC}_{1: 2}, 25 \mathrm{~g}$ of soil from the dried sample was taken in a beaker and $50 \mathrm{ml}$ distilled water was added. A solution was made and kept for 24 hour then filter the water and measure the EC of water with the help of EC meter.

\subsection{Yield and yield parameters}

Plants height was measured from top point to root shoot with the help of centimeter scale at every 30 days interval. Weight of fruits was recorded of each treatment at every harvesting and was expressed in grams. Mean weight of chilli were taken as average fruit weight of each treatment. Chilli per plot at every picking was weighed and summed to get the chilli yield per plot which was converted and expressed in tonnes/ha.

\subsection{Water use efficiency}

Water use efficiency (WUE) represents the relation between yield and irrigation water. WUE of different treatment was calculated in term of fruit yield per hectare to the amount of water used per hectare.

\subsection{Nitrogen use efficiency}

Nitrogen use efficiency (NUE) represents the relation between yield and amount of nitrogen applied. NUE of different treatment was calculated in term of fruit yield per hectare to the amount of nitrogen applied per hectare.

\section{Results and Discussion}

Water required by plant per day was calculated by equation 1 . So total water required by a plant for whole period was 55.02 liters and for one plot 880.32 liters in drip system. On the other hand total water applied in surface was 1634 liters per plot. So in drip system $46.13 \%$ water was saved as compared to surface irrigation.

\subsection{Effect of irrigation frequency}

Moisture content, taken at regular interval of 15 days, spatial and temporal contour maps were plotted for 45, 75 and 105 DAT. Radial distance from the plant and depth from the soil surface were taken on horizontal axis and vertical axis, respectively. The study of wetting patterns was the function of radial distance from the plant or dripper and the depth from the soil surface. Wetting pattern of 45, 75 and 105 DAT under daily irrigation treatments in
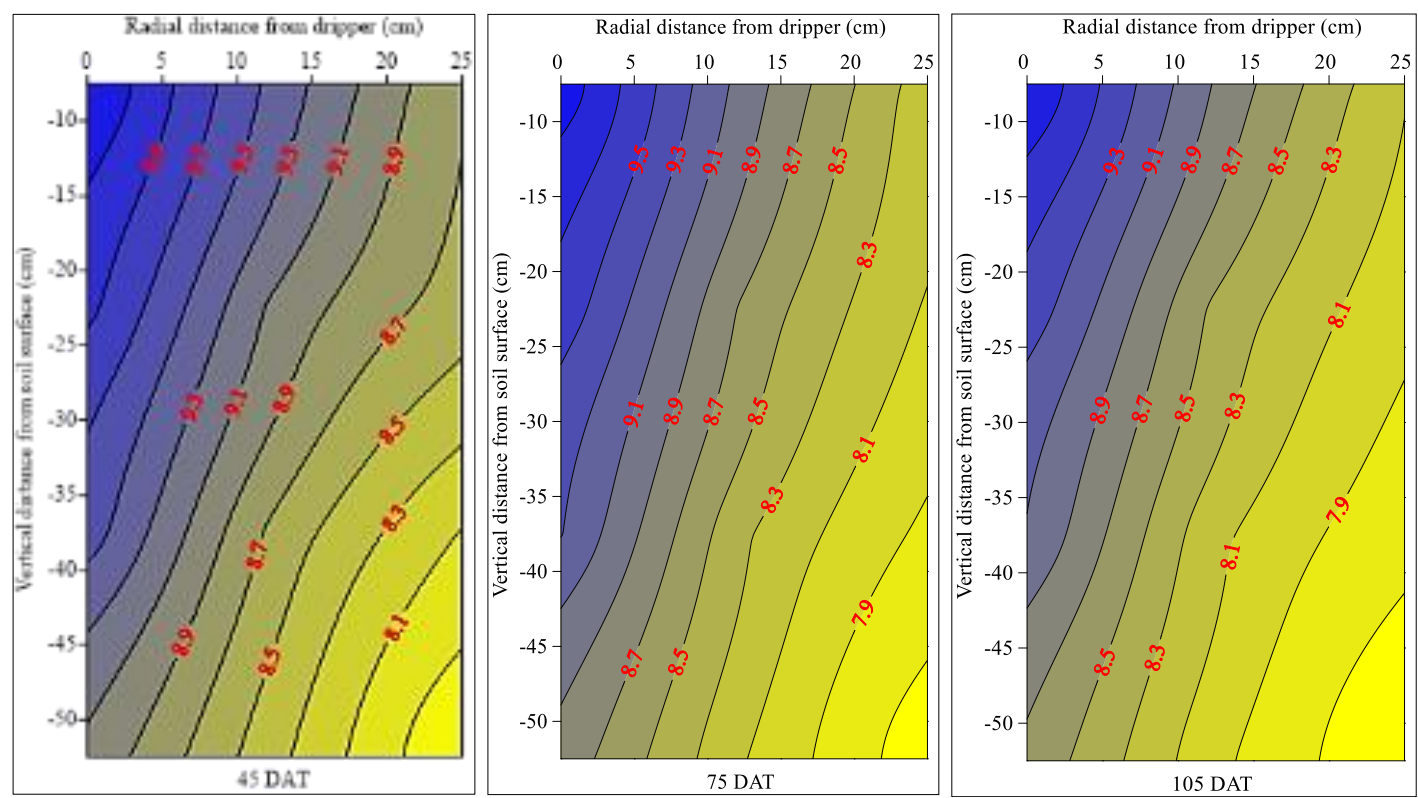

Fig 1: Spatial and temporal movement of moisture content in $\mathrm{I}_{1} \mathrm{~F}_{1}$. 

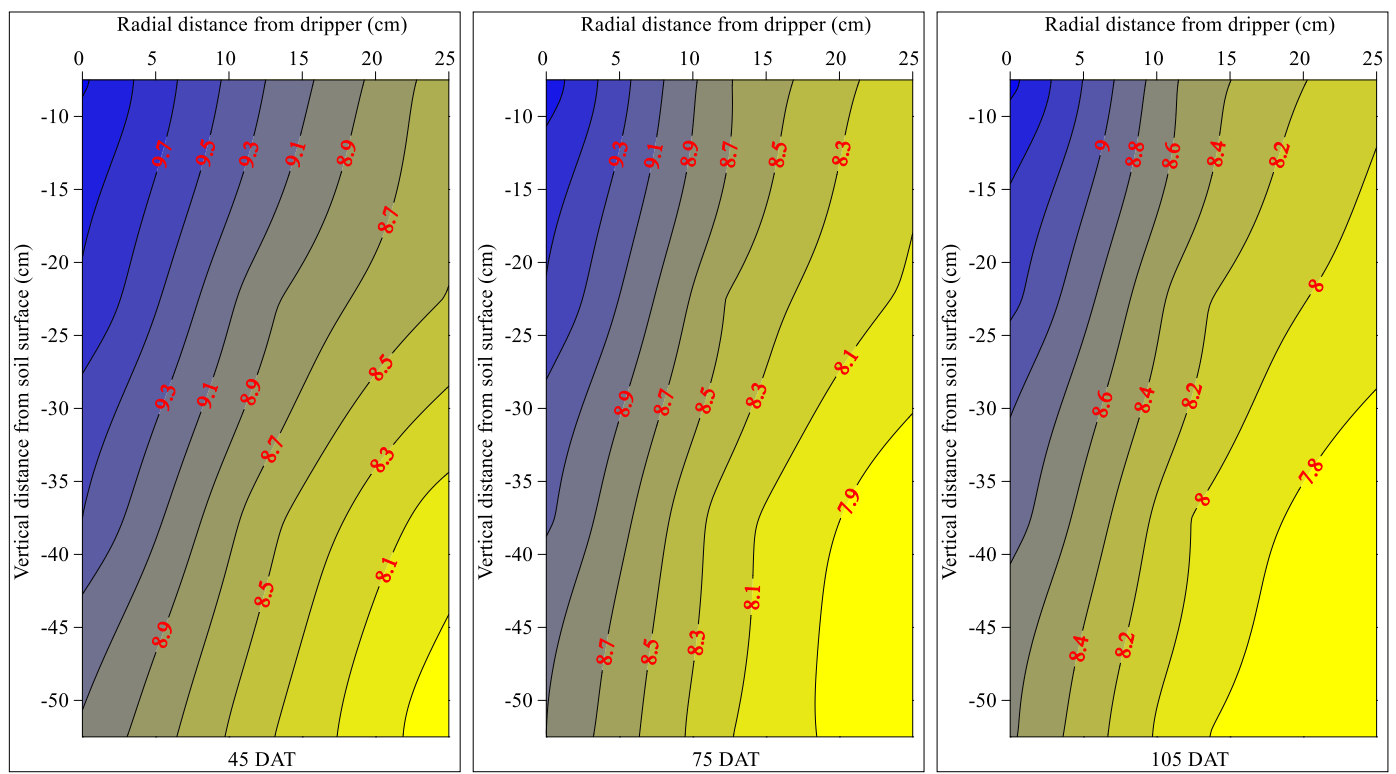

Fig 2: Spatial and temporal movement of moisture content in $\mathrm{I}_{1} \mathrm{~F}_{2}$.
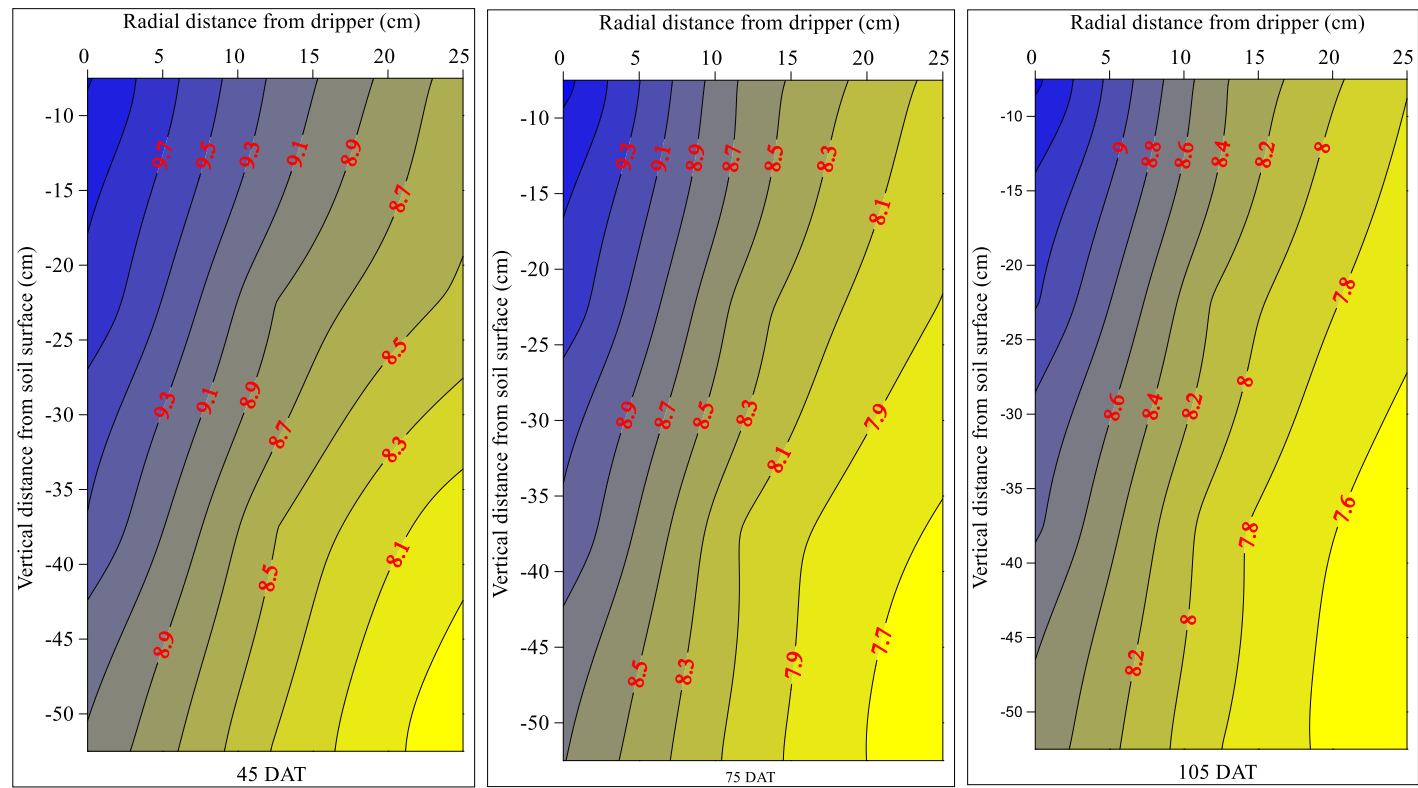

Fig 3: Spatial and temporal movement of moisture content in $\mathrm{I}_{1} \mathrm{~F}_{3}$.
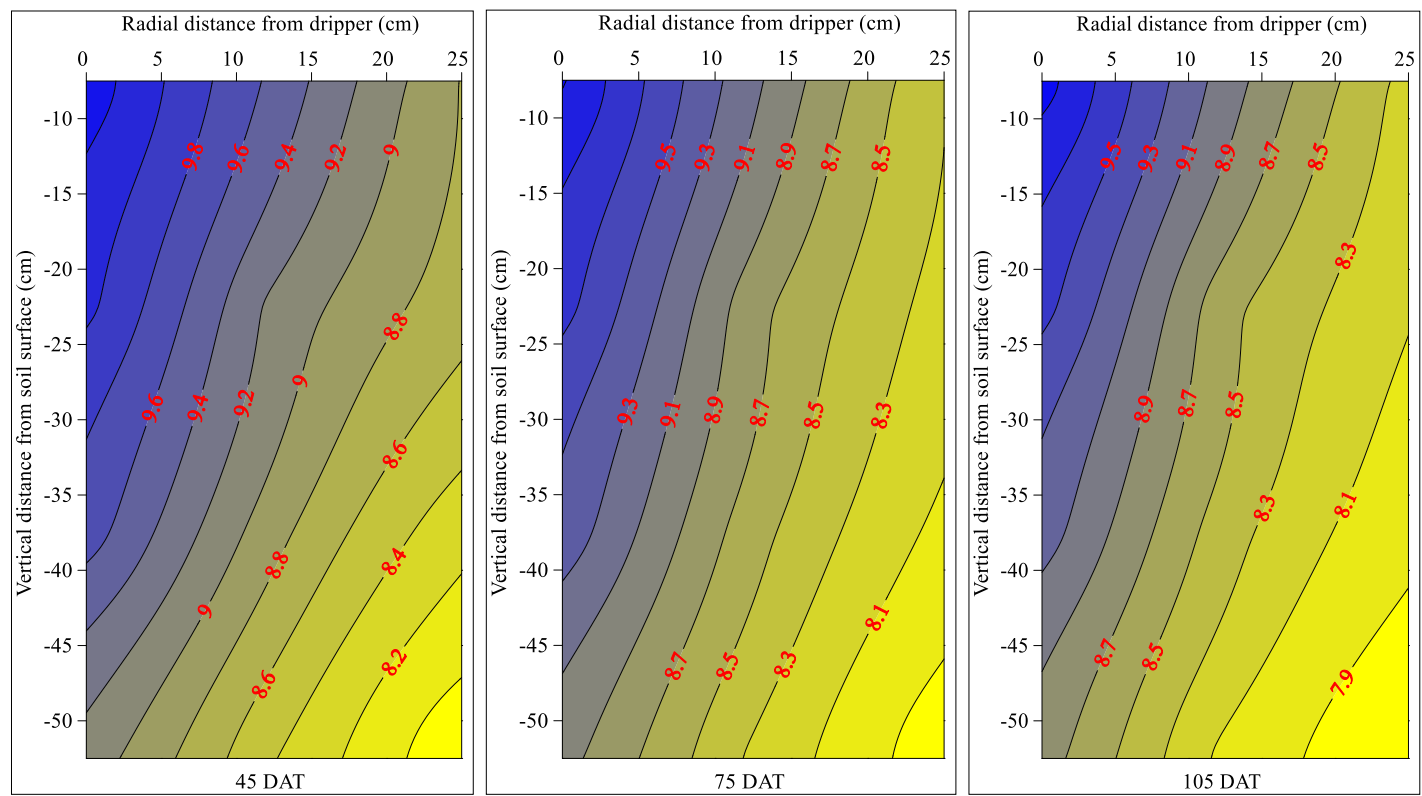

Fig 4: Spatial and temporal movement of moisture content in $\mathrm{I}_{2} \mathrm{~F}_{1}$. 

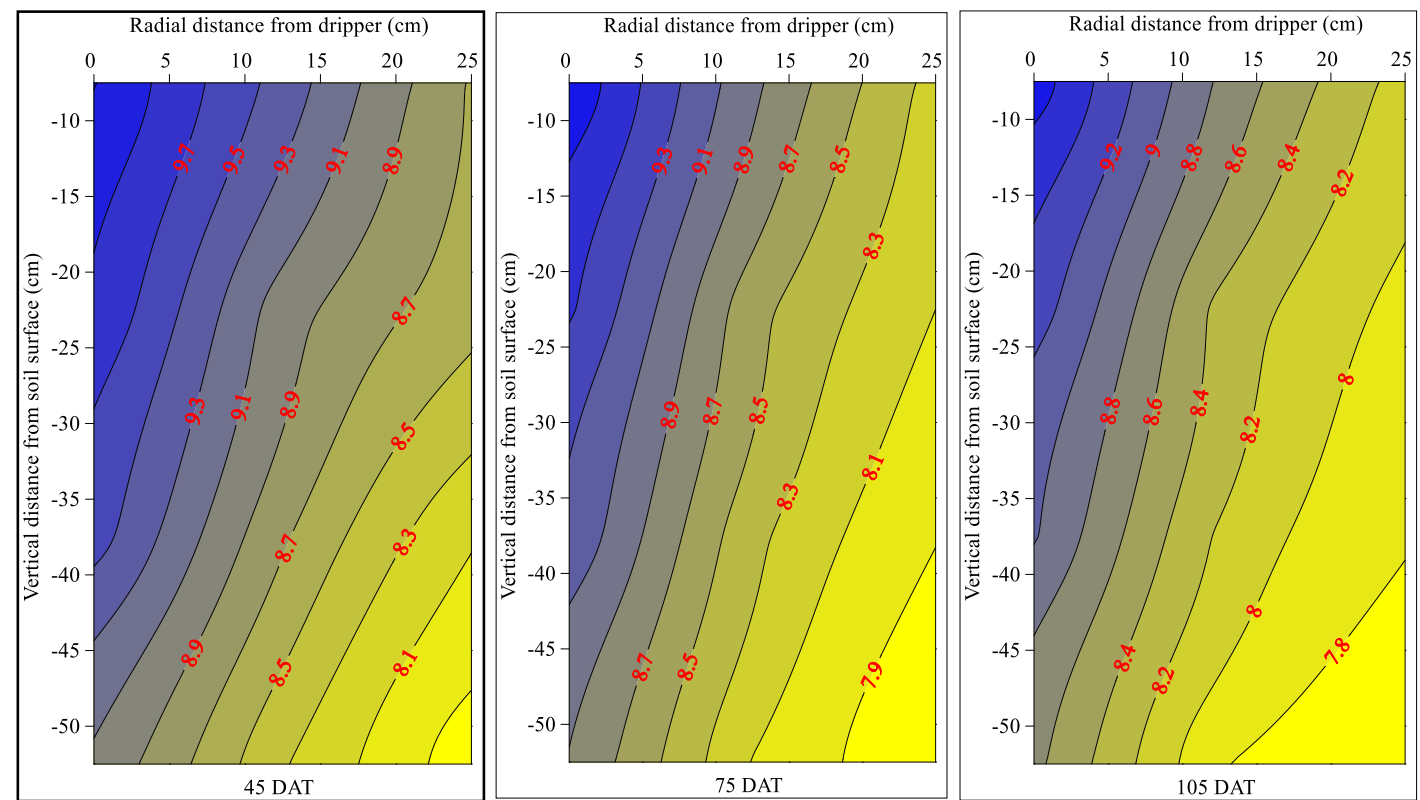

Fig 5: Spatial and temporal movement of moisture content in $\mathrm{I}_{2} \mathrm{~F}_{2}$
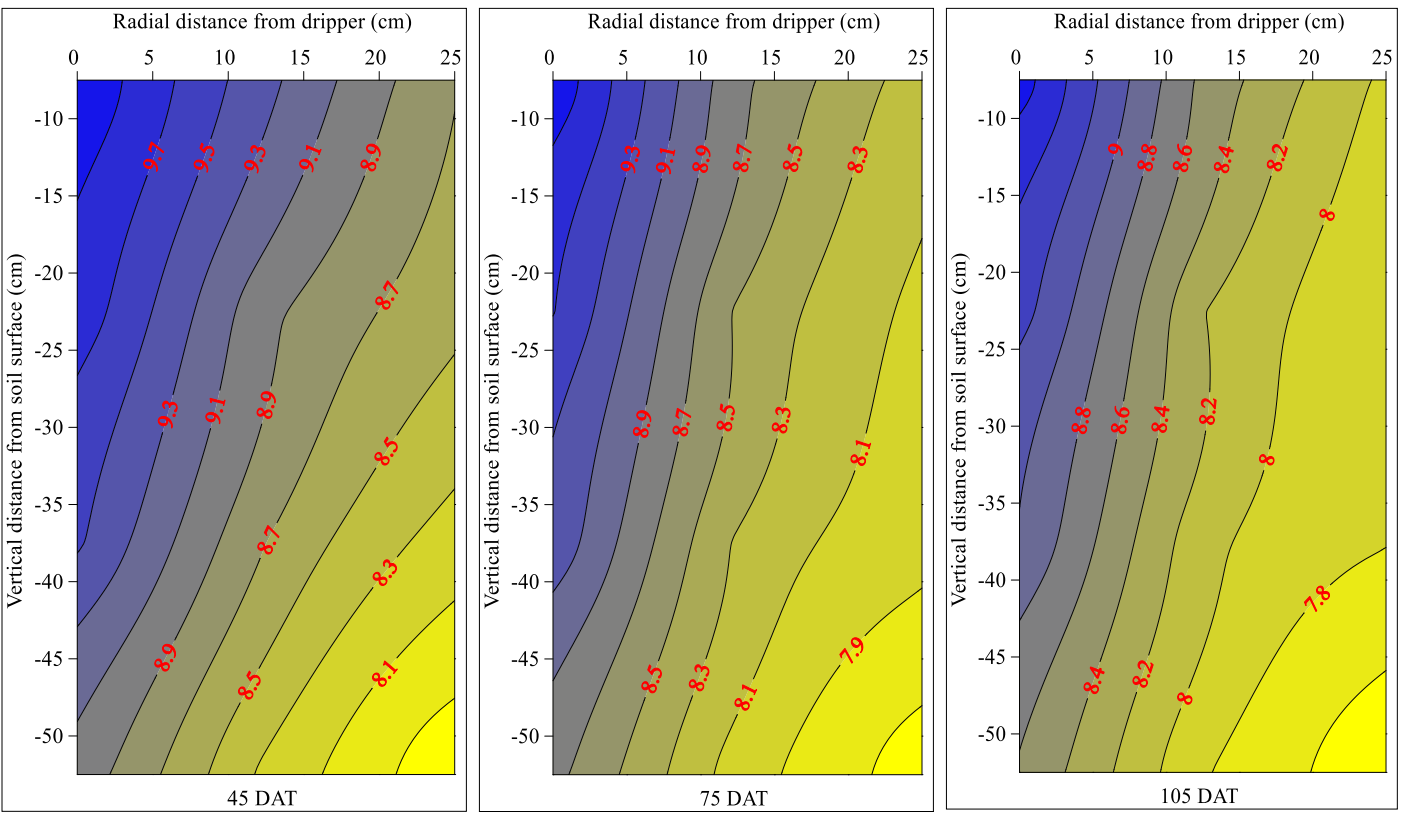

Fig 6: Spatial and temporal movement of moisture content in $\mathrm{I}_{2} \mathrm{~F}_{3}$.

$\mathrm{I}_{1} \mathrm{~F}_{1}, \mathrm{I}_{1} \mathrm{~F}_{2}$ and $\mathrm{I}_{1} \mathrm{~F}_{3}$ are shown in Fig 1 to 3 , respectively and for alternate irrigation treatments i.e. $\mathrm{I}_{2} \mathrm{~F}_{1}, \mathrm{I}_{2} \mathrm{~F}_{2}$ and $\mathrm{I}_{2} \mathrm{~F}_{3}$ are shown in Figure 4 to 6.

As expected average moisture content near the plant (below dripper) was more than at $12.5 \mathrm{~cm}$ and at $12.5 \mathrm{~cm}$, it was more than $25 \mathrm{~cm}$. The trend of moisture content in all the treatment was nearly same. Soil moisture content depleted with time in upper layer as well as in lower layers with the growth of the crop. In $\mathrm{I}_{1} \mathrm{~F}_{1}$ treatment near the plant, the contour of $9.1 \%$ moisture content was at a depth of $50 \mathrm{~cm}$ in the contour map of 45 DAT. This contour rose up with time and reached to $35 \mathrm{~cm}$ depth in the contour map of 105 DAT which indicates the extraction of more water by roots as its length and density increase with time. Upward movement of contour or depletion in soil moisture content with time may be due to extraction of water by the roots before reaching the lower parts of the root zone (Sharma et al. 2013). At the soil surface, this contour line $(9.1 \%)$ is touching the surface at 18 $\mathrm{cm}$ distance from the plant in 45 DAT contour maps. This contour moved towards the plant with time and reached to 9 $\mathrm{cm}$ in the contour map of 105 DAT which indicates the decline in the moisture content in the horizontal direction too with the crop growth.

On comparing the contours of irrigation frequency treatments, it was observed that the pattern of moisture content in the root zone varied with frequency. On comparing the daily irrigation frequency $\left(\mathrm{I}_{1} \mathrm{~F}_{3}\right)$ with alternate day irrigation frequency $\left(\mathrm{I}_{2} \mathrm{~F}_{3}\right)$ at 45 DAT, $9.1 \%$ moisture content contour is at 50 and $48 \mathrm{~cm}$, respectively near the plant but at $105 \mathrm{DAT}$, it rose up to a depth of 25 and $24 \mathrm{~cm}$, respectively. Results shows $\mathrm{I}_{1} \mathrm{~F}_{3}$ treatment of daily irrigation utilized a little higher root zone water and has higher yield than alternate day irrigation.

On comparing the contours of fertigation treatments, it was observed that the pattern of moisture content in the root zone varied with fertigation level. On comparing the fertigation level of $75 \%$ RDN $\left(\mathrm{I}_{1} \mathrm{~F}_{1}\right)$ with $125 \% \mathrm{RDN}\left(\mathrm{I}_{1} \mathrm{~F}_{3}\right)$ at $45 \mathrm{DAT}$, $9.1 \%$ moisture content contour is at the same depth but at 105 DAT, it rose up from a depth of $50 \mathrm{~cm}$ to $35 \mathrm{~cm}$ in $\mathrm{I}_{1} \mathrm{~F}_{1}$ and to 
$25 \mathrm{~cm}$ in $\mathrm{I}_{1} \mathrm{~F}_{3}$. In $100 \% \operatorname{RDN}\left(\mathrm{I}_{1} \mathrm{~F}_{2}\right) 9.1 \%$ moisture content contour rose up from a depth of $50 \mathrm{~cm}(45$ DAT) to $27 \mathrm{~cm}$ (105 DAT). Similar pattern was also observed in alternate day irrigation treatment. It is concluded that $125 \%$ and $100 \%$ RDN treatments extracted more water as compared to $75 \%$ RDN in both frequency but among $100 \%$ and $125 \%$ RDN this difference is negligible.

\subsection{Salt dynamics under different treatments of drip irrigation}

Same amount of water, having EC of $2.5 \mathrm{dS} \mathrm{m} \mathrm{m}^{-1}$, was applied to all the drip irrigation treatments. Salt observations recorded from different depth at regular interval of 15 days, spatial and temporal contour maps were plotted for 45, 75 and 105 days after transplanting. Horizontal axis of the figures shows radial distance from the dripper (near the plant) and vertical axis shows depth from the soil surface. Thus, the salt distribution patterns under daily and alternate day irrigation with different fertigation level treatments i.e. $\mathrm{I}_{1} \mathrm{~F}_{1}, \mathrm{I}_{1} \mathrm{~F}_{2}, \mathrm{I}_{1} \mathrm{~F}_{3}, \mathrm{I}_{2} \mathrm{~F}_{1}, \mathrm{I}_{2} \mathrm{~F}_{2}$ and $\mathrm{I}_{2} \mathrm{~F}_{3}$ at 45, 75 and 105 DAT are shown in Figures 7 to 12 . From contour maps in Figure 7, it was observed that as the time increased the salts accumulation increased in the root zone but more salts were accumulated at the outer periphery of wetting zone as compared to near the dripper (plant). Similar results were observed in all treatments. On comparing the Figures 7, 8 and 9 for daily treatments and Figures 10, 11 and 12 for alternate day irrigation treatments, no significant difference of salts accumulation between fertigation levels was observed. On comparing the frequencies of irrigation (Figures 7 to 9 and
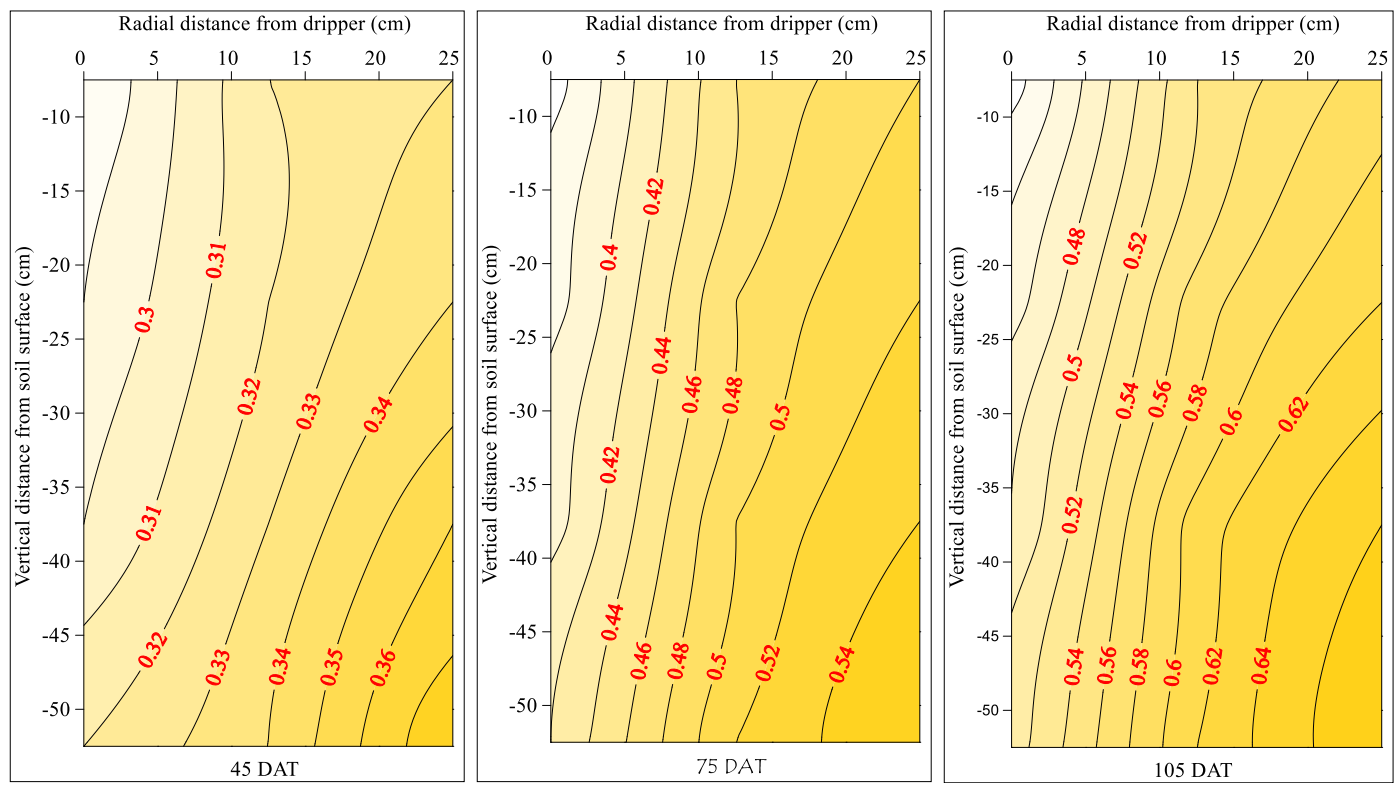

Fig 7: Spatial and temporal movement of salts in $\mathrm{I}_{1} \mathrm{~F}_{1}$
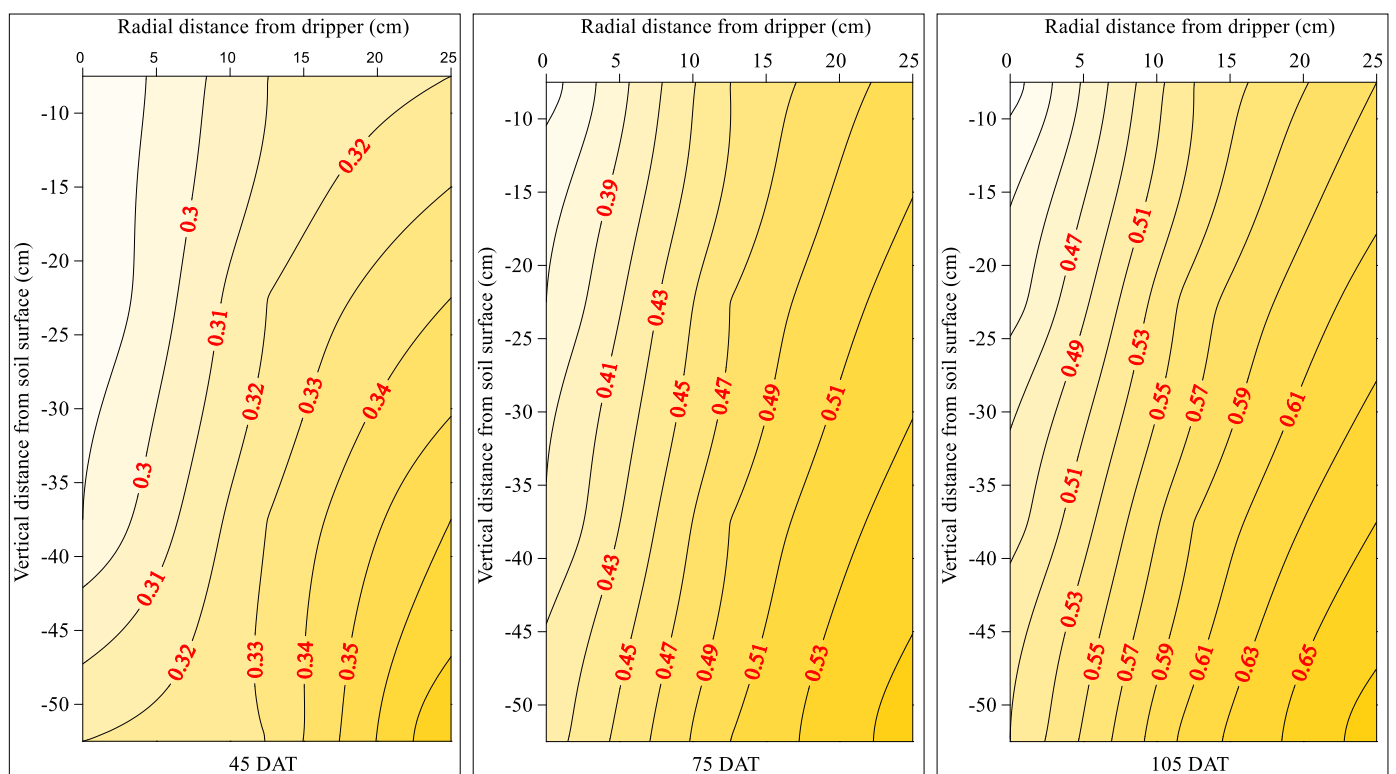

Fig 8: Spatial and temporal movements of salts in $\mathrm{I}_{1} \mathrm{~F}_{2}$ 

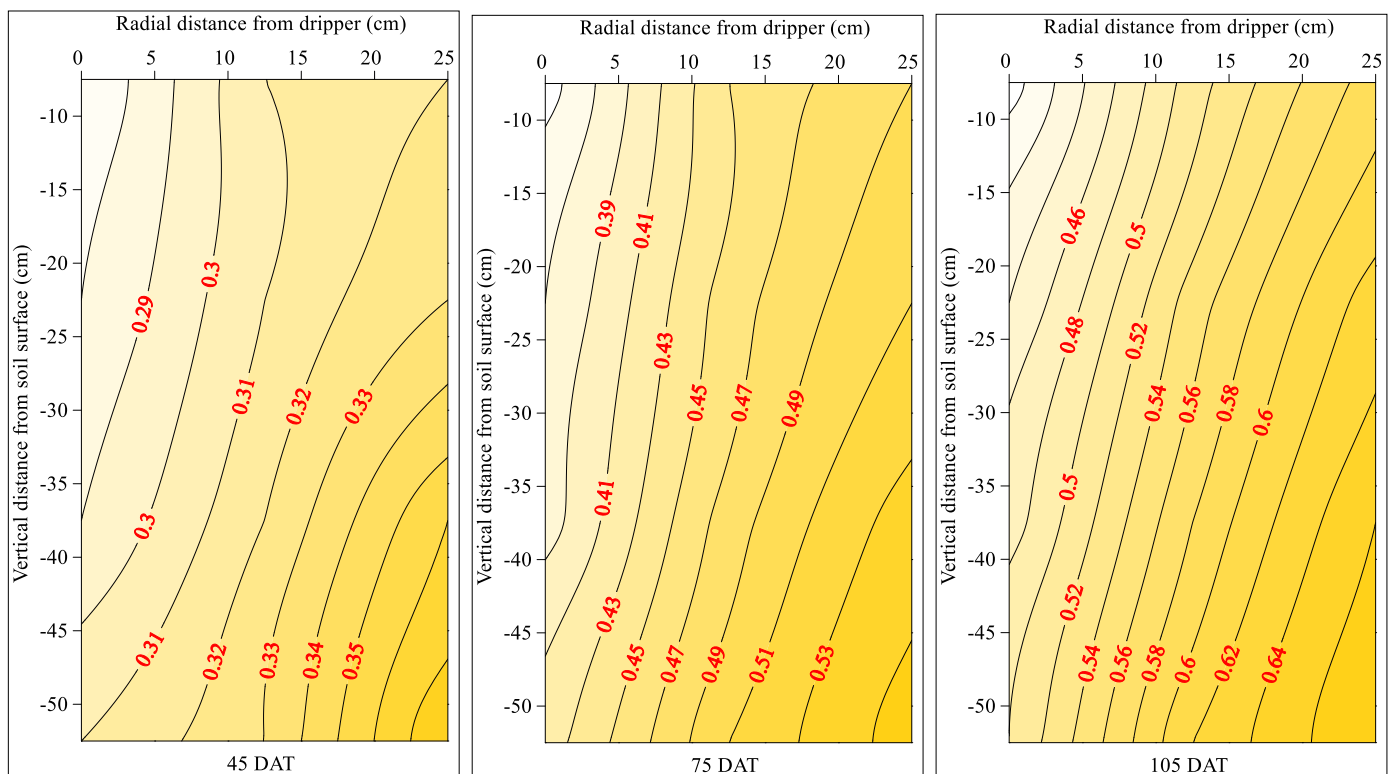

Fig 9: Spatial and temporal movements of salts in $\mathrm{I}_{1} \mathrm{~F}_{3}$.
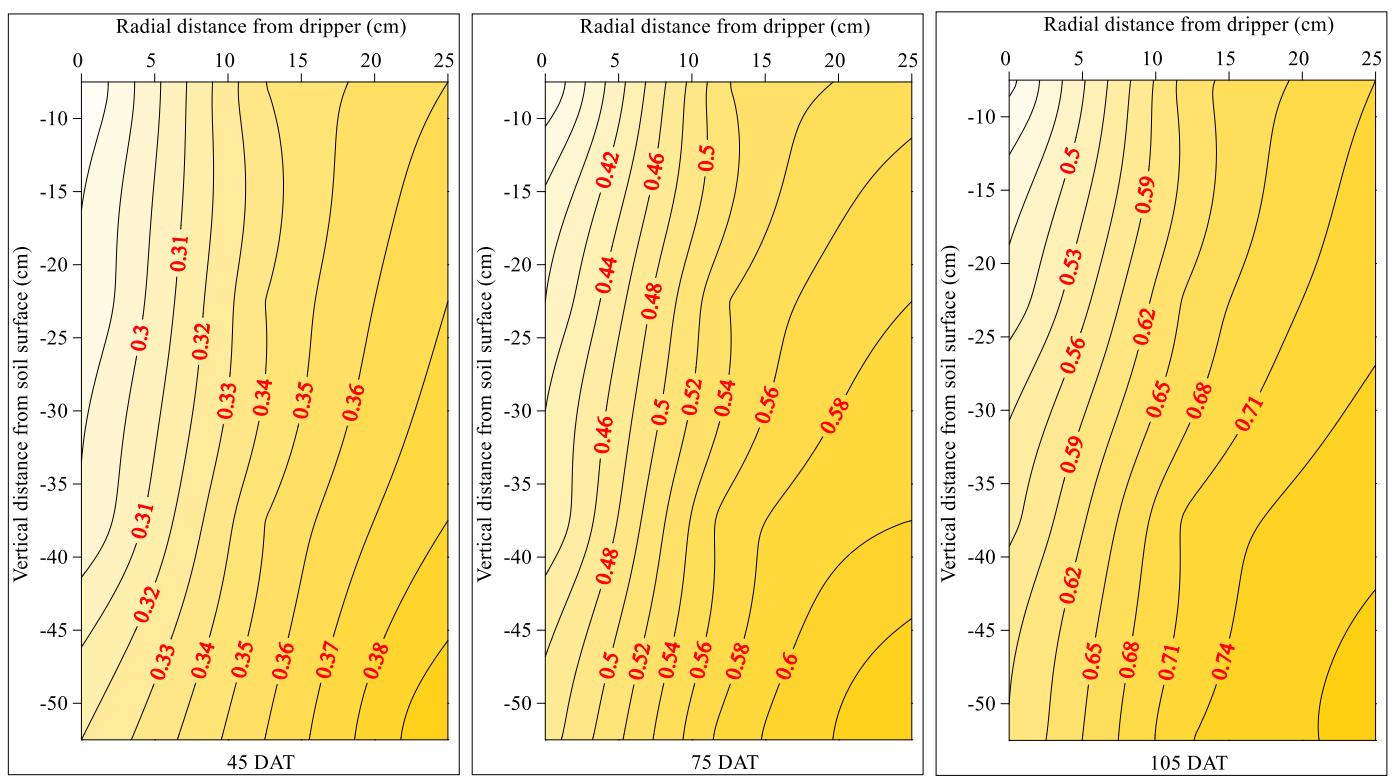

Fig 10: Spatial and temporal movements of salts in $\mathrm{I}_{2} \mathrm{~F}_{1}$
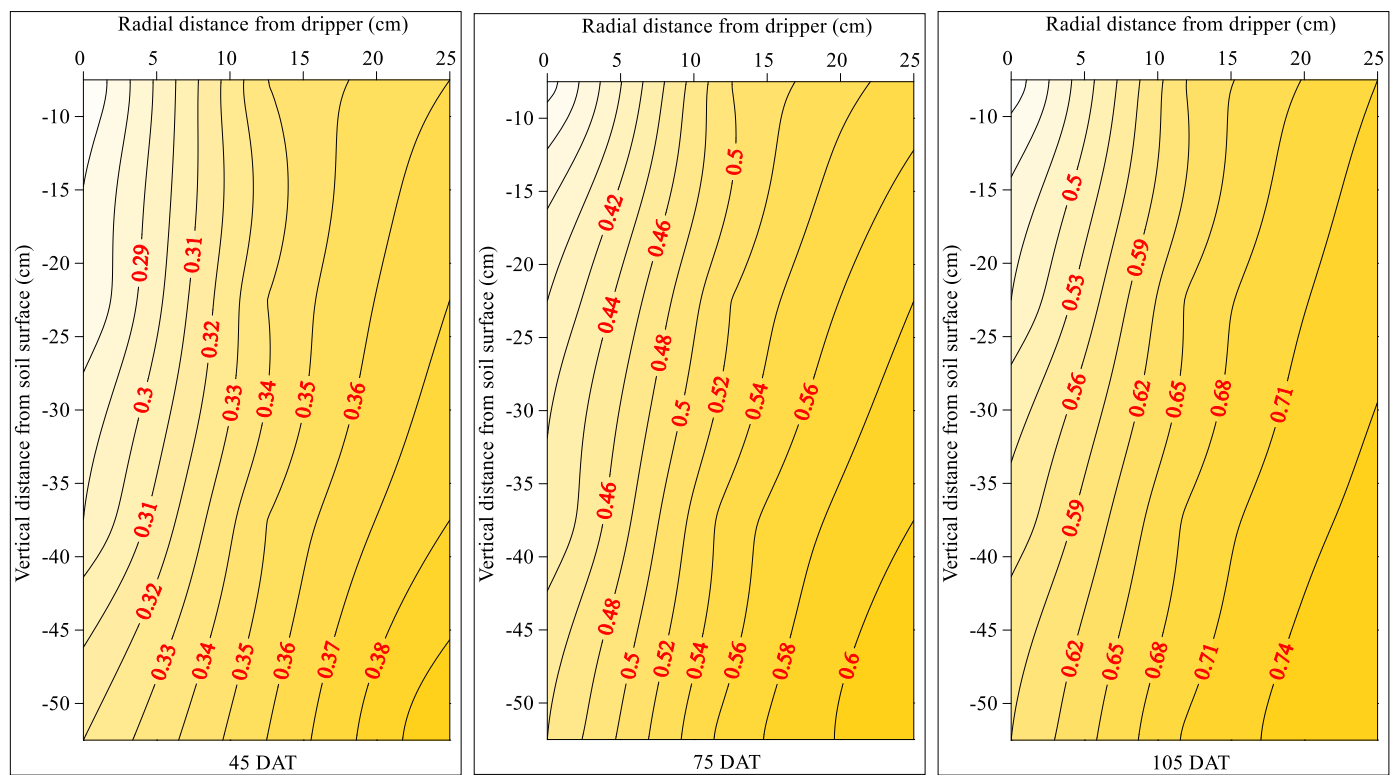

Fig 11: Spatial and temporal movements of salts in $\mathrm{I}_{2} \mathrm{~F}_{2}$ 

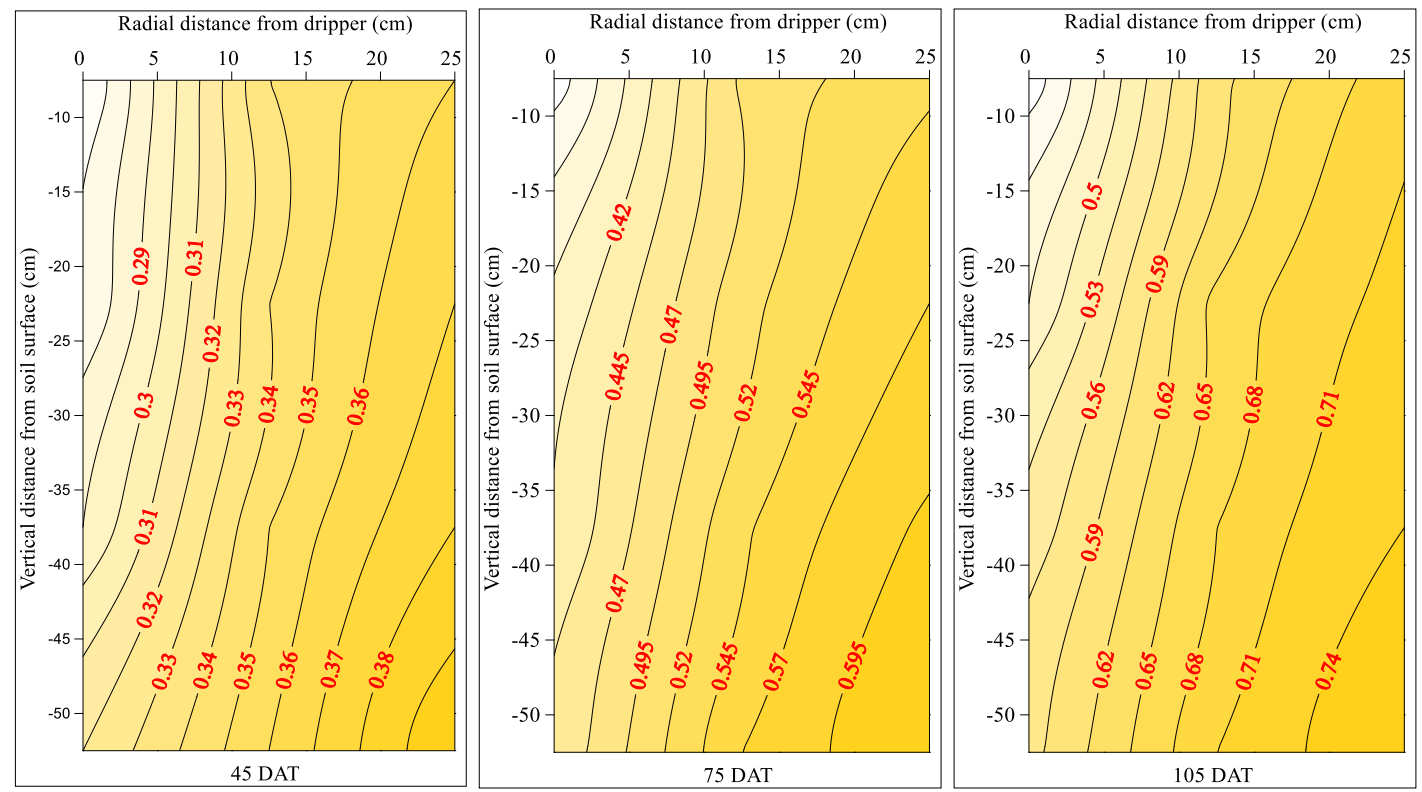

Fig 12: Spatial and temporal movements of salts in $\mathrm{I}_{2} \mathrm{~F}_{3}$

Figures 10 to 12 ) more salts were accumulated in alternate day irrigation treatments. The lowest root zone salinity was recorded in $\mathrm{I}_{1} \mathrm{~F}_{3}\left(0.55 \mathrm{dS} \mathrm{m}^{-1}\right)$ and the highest mean root zone salinity $\left(0.65 \mathrm{dS} \mathrm{m}^{-1}\right)$ was recorded in $\mathrm{I}_{2} \mathrm{~F}_{1}$ after 105 DAT. So, in alternate day irrigation treatment results were accumulated in root zone as compared to daily irrigation. Higher salinity in alternate day treatments was caused by capillary rise of salts to the root zone. Increasing irrigation interval increased the soil moisture tension, which caused capillary rise of water along with salts (Sharmiladevi et al., 2017) ${ }^{[19]}$.

In other words, there is much impact of irrigation frequency on salt concentration in root zone than fertigation level. Increased frequency of irrigation leaches the salts from the root zone which develops lower soil salinity (Sharmiladevi et al., 2017) ${ }^{[19]}$. So daily irrigation treatments has lower salinity in root zone and utilized more root zone water and hence higher yield as compared to alternate day.

\subsection{Yield and yield parameters}

Average height of chilli plants of daily irrigation treatments was more than alternate day irrigation treatment in the respective fertigation treatments. In daily irrigation at 120 DAT,

8.0 and $10.5 \%$ higher plant height was recorded in $\mathrm{I}_{1} \mathrm{~F}_{2}$ and $I_{1} F_{3}$, respectively in comparison to $I_{1} F_{1}$ treatment. In alternate day irrigation at $120 \mathrm{DAT}, 14.0$ and $15 \%$ higher plant height was recorded in $\mathrm{I}_{2} \mathrm{~F}_{2}$ and $\mathrm{I}_{2} \mathrm{~F}_{3}$, respectively in comparison to $\mathrm{I}_{2} \mathrm{~F}_{1}$ treatment. Plant height $(64.03 \mathrm{~cm})$ in $\mathrm{I}_{1} \mathrm{~F}_{3}$ treatment was recorded highest among all the treatment. However the difference between $125 \%$ and $100 \%$ RDN is not much as compared to $75 \%$ RDN among both irrigation practices and similar results have been reported by Vijayakumar et al. (2010) and Wahocho et al. (2016) in chilli. Plant height of surface irrigation (100\% RDN) was more than $75 \%$ RDN treatments of both frequencies.
Average fruit weight, length and thickness of chilli fruit were given in Table 3. All the parameters were higher in daily irrigation treatments as compared to alternate day irrigation and surface irrigation. In comparison, of fertigation treatments, all parameters were higher in $125 \%$ RDN treatments but there was no significant difference from $100 \%$ RDN treatments. In daily drip irrigation, fruit weight, length and thickness were recorded 17.0, 16.4 and 19.2\% higher, respectively, in $\mathrm{I}_{1} \mathrm{~F}_{2}$ and 19.0, 19.6 and $20.8 \%$ higher, respectively, in $\mathrm{I}_{1} \mathrm{~F}_{3}$, in comparison to $\mathrm{I}_{1} \mathrm{~F}_{1}$ treatment. In alternate day treatments, fruit weight, length and thickness were recorded 19.2, 29.1 and $25.2 \%$ higher, respectively, in $\mathrm{I}_{2} \mathrm{~F}_{2}$ and $22.6,31.9$ and $27.7 \%$ higher, respectively, in $\mathrm{I}_{2} \mathrm{~F}_{3}$ in comparison to $\mathrm{I}_{2} \mathrm{~F}_{1}$ treatment. Results revealed that increased nitrogen levels has also increases the fruit weight, length and thickness, but beyond a level, increment in nitrogen fertigation is not much effective. No significant difference was observed among the weight, length and thickness of fruit between 100 and $125 \%$ RDN. So in term of fruit parameters, $100 \%$ RDN treatment is equally good as $125 \% \mathrm{RDN}$ in both frequencies.

In daily irrigation, $28.2 \%$ and $34.0 \%$ more yield was obtained in $\mathrm{I}_{1} \mathrm{~F}_{2}$ and $\mathrm{I}_{1} \mathrm{~F}_{3}$ in comparison to $\mathrm{I}_{1} \mathrm{~F}_{1}$ and in alternate day irrigation, $27.4 \%$ and $32.9 \%$ more yield was obtained in $\mathrm{I}_{2} \mathrm{~F}_{2}$ and $\mathrm{I}_{2} \mathrm{~F}_{3}$ in comparison to $\mathrm{I}_{2} \mathrm{~F}_{1}$. Similar observations were recorded by Nalawade (2010) in cabbage, Kumar (2010) in maize, Vasu (2011) ${ }^{[26]}$ in cabbage and Kumar et al. (2017) in tomato. Under both irrigation frequency, yield under 100 and $125 \%$ RDN was statistically at par but significantly higher than $75 \%$ RDN. The highest yield $\left(10.69 \mathrm{t} \mathrm{ha}^{-1}\right)$ was obtained under daily drip irrigation with $125 \% \mathrm{RDN}\left(\mathrm{I}_{1} \mathrm{~F}_{3}\right)$, followed by $100 \% \mathrm{RDN}\left(\mathrm{I}_{1} \mathrm{~F}_{2}\right)$ having $10.23 \mathrm{t} \mathrm{ha}^{-1}$ yield (Figure 13 ). On comparing the frequencies of drip irrigation, daily irrigation treatments obtained $9.1 \%, 10.8 \%$ and $11.38 \%$ higher yield than alternate day 
Table 3: Average plant height, fruit weight, fruit size and yield of chilli in different treatments

\begin{tabular}{|c|c|c|c|c|}
\hline \multicolumn{5}{|c|}{ Plant height $(\mathrm{cm})$ at 120 DAT } \\
\hline \multirow{2}{*}{ Irrigation frequency } & \multicolumn{4}{|c|}{$\begin{array}{c}\text { Fertigation level } \\
\end{array}$} \\
\hline & $\mathbf{F}_{1}$ & $\mathbf{F}_{2}$ & $\mathbf{F}_{3}$ & Mean \\
\hline $\mathbf{S}_{\mathbf{i}}$ & - & 58.45 & - & - \\
\hline $\mathbf{I}_{1}$ & 57.95 & 62.58 & 64.03 & 61.52 \\
\hline $\mathbf{I}_{2}$ & 54.05 & 61.62 & 62.52 & 59.39 \\
\hline Mean & 56.00 & 62.10 & 63.28 & \\
\hline C.D. (5\%) & \multicolumn{3}{|c|}{\begin{tabular}{l|l|l}
$\mathrm{I}=1.351$ & $\mathrm{~F}=1.559$ & \\
\end{tabular}} & $\mathrm{IxF}=\mathrm{NA}$ \\
\hline \multicolumn{5}{|c|}{ Fruit weight $(\mathrm{g})$} \\
\hline $\mathbf{S}_{\mathrm{i}}$ & - & 6.95 & - & - \\
\hline $\mathbf{I}_{1}$ & 6.60 & 7.72 & 7.86 & 7.40 \\
\hline $\mathbf{I}_{2}$ & 6.15 & 7.33 & 7.54 & 7.01 \\
\hline Mean & 6.38 & 7.53 & 7.70 & \\
\hline C.D. $(5 \%)$ & \multicolumn{2}{|c|}{\begin{tabular}{l|l}
$\mathrm{I}=\mathrm{NA}$ \\
\end{tabular}} & $\mathrm{F}=0.339$ & $\mathrm{IxF}=\mathrm{NA}$ \\
\hline \multicolumn{5}{|c|}{ Fruit length $(\mathrm{cm})$} \\
\hline $\mathbf{S}_{\mathbf{i}}$ & - & 8.46 & - & - \\
\hline $\mathbf{I}_{1}$ & 9.07 & 10.56 & 10.85 & 10.16 \\
\hline$I_{2}$ & 7.88 & 10.17 & 10.39 & 9.48 \\
\hline Mean & 8.46 & 10.36 & 10.62 & \\
\hline C.D. (5\%) & \multicolumn{2}{|c|}{\begin{tabular}{l|l}
$\mathrm{I}=\mathrm{NA}$ \\
\end{tabular}} & $\mathrm{F}=0.330$ & $\mathrm{IxF}=0.868$ \\
\hline \multicolumn{5}{|c|}{ Fruit thickness (cm) } \\
\hline $\mathbf{S}_{\mathrm{i}}$ & - & 1.35 & - & - \\
\hline $\mathbf{I}_{1}$ & 1.30 & 1.55 & 1.57 & 1.47 \\
\hline $\mathbf{I}_{2}$ & 1.19 & 1.49 & 1.52 & 1.40 \\
\hline Mean & 1.25 & 1.52 & 1.55 & \\
\hline C.D. $(5 \%)$ & \multicolumn{3}{|c|}{$\mid F=0.185$} & $\mathrm{IxF}=\mathrm{NA}$ \\
\hline \multicolumn{5}{|c|}{ Yield $\left(\mathrm{t} \mathrm{ha}^{-1}\right)$} \\
\hline $\mathbf{S}_{\mathrm{i}}$ & - & 8.25 & - & - \\
\hline $\mathbf{I}_{\mathbf{1}}$ & 7.98 & 10.23 & 10.69 & 9.63 \\
\hline $\mathbf{I}_{2}$ & 7.31 & 9.23 & 9.60 & 8.71 \\
\hline Mean & 7.64 & 9.73 & 10.15 & \\
\hline C.D. (5\%) & \multicolumn{2}{|c|}{\begin{tabular}{l|l}
$\mathrm{I}=0.797$ & $\mathrm{~F}$
\end{tabular}} & 0.677 & $\mathrm{IxF}=\mathrm{NA}$ \\
\hline
\end{tabular}

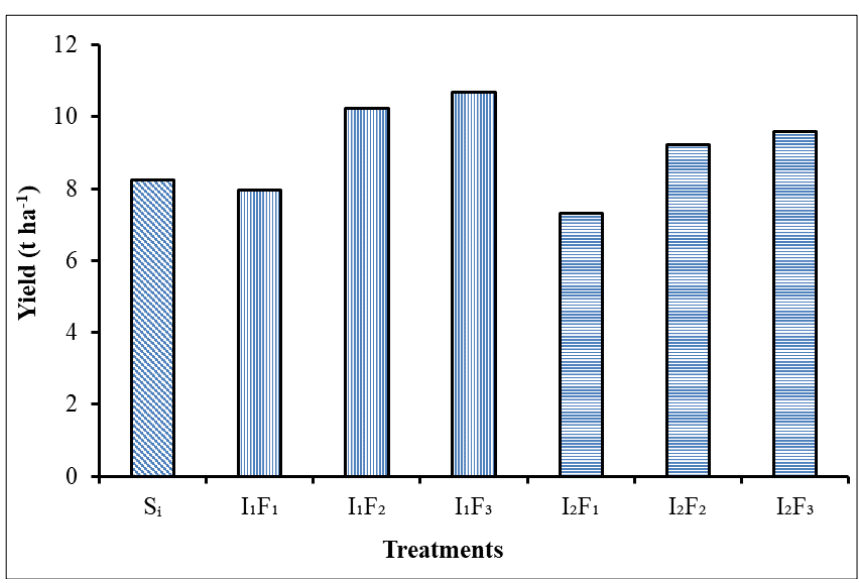

Fig 13: Yield (t ha-1) of chilli under different treatments

irrigation with respective fertigation level. Similarly, Hakkim (2014) ${ }^{[8]}$ in chilli and Sharmiladevi et al. (2017) ${ }^{[19]}$ in bhindi, recorded higher yield under daily drip irrigation frequency as compared to alternate day. Relatively higher yield under daily irrigation treatment as compare to alternate day irrigation treatment indicates that increase in irrigation frequency can manage saline water in better way. Daily drip irrigation with $100 \%$ RDN obtained $24.0 \%$ higher yield than flood irrigation with $100 \%$ RDN.

\subsection{Water use efficiency}

In surface irrigation, highest amount of water was used and have the lowest water use efficiency $\left(2.21 \mathrm{~kg} \mathrm{~m}^{-3}\right)$. Same amount of water was used in all treatments under drip system. Therefore, in drip irrigation WUE in a treatment is directly proportional to the yield obtained under that treatment. Among the drip irrigation, $\mathrm{I}_{1} \mathrm{~F}_{3}$ treatment has obtained the highest water use efficiency $\left(4.17 \mathrm{~kg} \mathrm{~m}^{-3}\right)$ and its lowest value $\left(3.19 \mathrm{~kg} \mathrm{~m}^{-3}\right)$ was obtained in $\mathrm{I}_{2} \mathrm{~F}_{1}$ treatment. On comparing fertigation levels, a significant reduction in WUE was observed when N-fertigation decreased from 100 to $75 \%$ RDN and no significant increment was observed when $\mathrm{N}$ fertigation increased 100 to $125 \%$. These results were supported by Kumar et al. (2017) in tomato. Under daily irrigation frequency, WUE under 100 and 125\% RDN was statistically at par but significantly higher than $75 \%$ RDN and similar results were obtained under alternate day irrigation frequency. On comparing the different percentage of RDN irrespective of irrigation frequencies, no significant difference in WUE was recorded by applying 75\% RDN but under 100 and $125 \% \mathrm{RDN}$, its value was significant higher in daily irrigation treatment than alternate day irrigation treatment. Therefore, frequent application of water increased the WUE under marginal water use.

\subsection{Nitrogen use efficiency}

Nitrogen use efficiency is directly proportional to the yield and inversely proportional to nitrogen applied as fertilizer. In daily irrigation, $3.8 \%$ and $19.6 \%$ low NUE was recorder in $\mathrm{I}_{1} \mathrm{~F}_{2}$ and $\mathrm{I}_{1} \mathrm{~F}_{3}$ in comparison to $\mathrm{I}_{1} \mathrm{~F}_{1}$ and in alternate day irrigation, $5.3 \%$ and $21.2 \%$ low NUE was obtained in $\mathrm{I}_{2} \mathrm{~F}_{2}$ and $\mathrm{I}_{2} \mathrm{~F}_{3}$ in comparison to $\mathrm{I}_{2} \mathrm{~F}_{1}$. On comparing fertigation levels, NUE (daily drip irrigation) under $\mathrm{I}_{1} \mathrm{~F}_{1}$ and $\mathrm{I}_{1} \mathrm{~F}_{2}$ were significantly different from $\mathrm{I}_{1} \mathrm{~F}_{3}$ and similar results were obtained under alternate day irrigation. With respect to irrigation frequencies, NUE was found significantly different in all RDN levels. The highest NUE (172.2 kg of chilli per $\mathrm{kg}$ of Nitrogen) was obtained under daily drip irrigation with $75 \%$ RDN $\left(\mathrm{I}_{1} \mathrm{~F}_{1}\right)$, followed by $100 \% \mathrm{RDN}\left(\mathrm{I}_{1} \mathrm{~F}_{2}\right)$ having 165.6 $\mathrm{kg}$ of chilli per $\mathrm{kg}$ of Nitrogen. These results were supported by Vijaykumar et al. (2010) in chilli and Kumar (2010) in maize crop. On comparing the frequencies of drip irrigation, daily irrigation treatments obtained $8.4 \%, 9.8 \%$ and $10.2 \%$ higher NUE than alternate day irrigation with respective fertigation level. Relatively higher yield under daily irrigation treatment as compare to alternate day irrigation treatment indicates that increase in irrigation frequency can manage nitrogen in better way as less water per irrigation was applied in daily irrigation treatment and thus have less leaching losses. Daily drip irrigation with $100 \%$ RDN obtained $23.9 \%$ higher NUE than flood irrigation with $100 \%$ RDN. Thus, under marginal saline water, higher nitrogen use efficiency can be obtained by increasing irrigation frequencies and reducing $\mathrm{RDN}$.

\section{Conclusion}

From all the observation, it was concluded that salinity can be lowered by increasing irrigation frequency and got better result in crop production under saline water through drip system. So daily drip irrigation treatments were superior to alternate day irrigation treatments and got better results under saline water. On comparing drip with surface irrigation, 10 to $30 \%$ higher results were recorded under drip irrigation in different yield and yield attribute parameters of chilli crop. Results show, in drip system more than $43 \%$ water could be saved as compared to surface irrigation. N-fertigation level supply beyond $100 \%$ RDN had no significant effect on yield and WUE even reduced the NUE, whereas, with the reduction of RDN from 100 to $75 \%$, significance reduction was observed in yield and other parameters. 


\section{References}

1. Abdel Gawad G, Arslan A, Gaihbe A, Kadouri F. The effects of saline irrigation water management and salt tolerant tomato varieties on sustainable production of tomato in Syria (1999-2002). Agricultural Water Management. 2005; 7839-53.

2. Agarwal N, Tamrakar SK, Tripathi MP, Tiwari RB. Response of cabbage under different levels of irrigation and fertigation through drip. International Journal of Current Microbiology and Applied Sciences. 2018; 6:750-759.

3. Brahmanapuduru G. Studies on irrigation and fertigation management on chilli (Capsicum annuum) under drip system. Unpublished master dissertation, Indira Gandhi Krishi Vishwavidyalaya, Raipur, India, 2017.

4. Dahal KC, Sharma MD, Dhakal DD, Shakya SM. Evaluation of heat tolerant chilli (Capsicum annuum 1.) Genotypes in western terai of Nepal. Journal of Institute of Agriculture and Animal Sciences. 2006; 27:59-64.

5. Fanish AS. Influnece of drip fertigation on water productivity and profitability of maize, African Journal of Agricultural Research. 2013; 8:3757-3763.

6. Gee GW, Bauder JW. Particle-size analysis. In a klute methods of soil analysis. part1. $2^{\text {nd }}$ edition agronomy monograph. American Society of Agronomy \& Soil Science Society of America, Madison, WI, 1986, 383411.

7. Gulshan M, Singh KG, Rakesh S, Mukesh S. Response of red hot pepper (Capsicum annum L.) to water and nitrogen under drip and check basin method of irrigation. Asian Journal of Plant Sciences. 2007; 6:815-820.

8. Hakkim AVM. Effect of site-specific drip fertigation on yield of chilli. IOSR Journal of Engineering (IOSRJEN), 2014; 04:33-41.

9. Haise HR, Donnan WW, Phelan JT, Lawhon LF, Shockley DG. The use of cylinder infiltrometers to determine the intake characteristics of irrigated soils. Agriculture Research Service and Soil Conservation Service, USDA, Washington DC, 1956.

10. Jackson ML. Soil Chemical Analysis, Prentice Hall of India Private Limited, New Delhi, 1967, 183-192.

11. Kadam JR, Bhingardeve SD, Walke VN. Effect of saline water and fertigation on the yield contributing parameters of brinjal. International Journal of Agricultural Sciences. 2007; 3(1):162-164.

12. Kaminwar SP, Rajagopal V. Fertilizer response and nutrient requirement of rain fed chillies in Andhra Pradesh. Fertilizer News. 1993; 36(7):21-26.

13. Kelley WP. Alkali soils, their formation, properties and reclamation. Rienhold, New York, 1951.

14. Khalkho D, Naik RK, Thakur AK, Bisen Y, Chandraker AK. Effective irrigation water management in Rabi Chilli for Bastar agro climatic zone. Scientific Research and Essays, alkali soils. United State Department of Agriculture Handbook no. 60. Washington, D.C. 2014; 8(48):2332-2335.

15. Olsen SR, Cole CV, Watanabe FS, Dean LA. Estimation of available phosphorus in soils by extraction with sodium bicarbonate. United State Department of Agriculture, Circular No, 1954, 939.

16. Schwab GO, Fangmeir DD, Elliot WJ, Frevert KR. Soil and Water Conservation Engineering. $4^{\text {th }}$ ed. John Wiley \& Sons Inc., Newyork, 1993.
17. Seckler D, Molden D, Barker R. Water scarcity in the twenty-first century. IWMI Water Brief 1. Colombo, Sri Lanka: International Water Management Institute, 1998.

18. Sharma P, Kumar S, Sharma SK, Jhorar RK. Salt and water dynamics under drip irrigation with different saline water in cabbage (Brassica oleracea (L.) var. capitata). Annals of Agricultural Biology Research. 2013; 29(1):89-92.

19. Sharmiladevi R, Ranghaswami MV, Rajendran V. Effect of irrigation frequency and quantity on soil salt distribution in the root zone of bhendi under drip irrigation. International Journal of Agriculture Sciences. 2017; 9:4787-4791.

20. Shashidhara KG. Response of chilli to drip irrigation and fertigation on a vertisol of malaprabha command area. Unpublished master dissertation, University of Agricultural Sciences, Dharwad, India, 2006.

21. Sivanappan RK, Ranghaswami MV. Technology to take 100 tons per acre in sugarcane. Kissan world. 2005; 32(10):35-38.

22. Subbiah B, Asija GL. A rapid procedure for estimation of available nitrogen in soils. Currents Science. 1956; 25:259-260.

23. Subbaiah K. Effect of varying levels of nitrogen and potassium on the growth attribute characteristics of chilli cv. CO-1. Proceedings of National Seminar on Production Technology of Tomato and Chillies, Coimbatore, India, 1983.

24. Togun AO, Akanbi WB, Dris R. Influence of compost and nitrogen fertilizer on growth, nutrient uptake and fruit yield of tomato (Lycopersicum esculentum). Journal Crop Resources. 2003; 98:40-56.

25. Tumbare AD, Bhoite SU. Effect of solid soluble fertilizers applied through fertigation on the growth and yield of chilli (Capsicum annuum L.). Indian Journal of Agricultural Sciences. 2002; 72(2):109-111.

26. Vasu D. Effect of fertigation on yield, quality and fertilizer use efficiency in cabbage (Brassica oleracia var. Capitata). Unpublished master dissertation. Acharya Nayukulu Gogineni Ranga Agricultural University, Rajendranagar, Hyderabad, India, 2011. 